\title{
Development of an Enzyme-Linked Immunosorbent Assay for the Organophosphorus Insecticide Bromophos
}

\author{
Won Chul Park, ${ }^{\dagger}$ Young Ae Cho, Yoo Jung Kim, ${ }^{\dagger}$ Bruce D. Hammock, ${ }^{\dagger}$ Yong Tae Lee, ${ }^{\dagger}$ and Hye-Sung Lee \\ Department of Food Science and Numition, Kunngpook National Liversin, Daegu 702-701, Korea \\ - Department of Biochemistry and Institute of Natural Siciences, Feungnam Linersity, Gyongsan 712-749, Korea \\ 'Department of Thomology and 'ancer Research Center, Lmiversity of C'aliforna, Davis, Californa 95616. LS.4 \\ Received June 4, 2002
}

\begin{abstract}
A competitive ena me-linked immuneserthent assay (FI,ISA) was developed for the quantitative detection of the organophosphorus insecticide bromophess. Three bromophow analogues (haptens) were synthesized and w ere coupled to carriter proteins to use as inmunogens or coating antigens. Rabbits were immunized with either one of two haptens coupled to bovine serum alhumin (BSA) lor production of polyclonal antibodics, and the sera were sereened against one of the haptens coupled to ovalbumin (OVA). Using the serum with highest specilicity and an enzyme tracer, an antibody-coaled EI.ISA was developed, which showed an IC 5 of $40 \mathrm{ng} /$ $\mathrm{mI}$, with a detection limit of $7 \mathrm{ng} / \mathrm{mI}$. The antibodies in this assay showed negligible cross-reactivity with other organophosphorus pesticides except with the insecticides chlorpyrilos and fenitrothion.
\end{abstract}

Key Words : Bromophos, Insecticide, Immunoassay, ELISA

\section{Introduction}

Due to the widespread use of pesticides. there is a growing concern over the entronmental contamination caused by their residues. The current methods such as gas chromatograply and high-performance liquid chromatograplyy have been used successfully for analysis of many pesticides. ${ }^{1}$ however. they require a high cosi and skilled analysts. and involve time-consuming sample preparation steps. Therefore. there is a growing demand for more rapid and cconomical methods for detcrmining pesticide residues. Immunoassays are being demonstrated as a suitable altenative to the traditional methods that can mect such demands. They began recently to gain acceplance as rast. sensitive. and costeffective tools for en iromental analy sis ${ }^{2-1}$

Bromophos [0,O-dimellyy ()-(4-bromo-2.5-dichloropheny. $]$ ) phosphorolhioatcl is a non-systcmic organophosphorus inseclicide and acaricide. which is effective against a wide range of insects. "The most sensitive and toxicologically relevant effect after administration of bromoplos is the imlibition of acety lcholinesterase activity in crythrocytes and brain. ${ }^{6}$ An ELISA for 1his pesticide las nol yel been reported.

The development of an immunoassay requires the production of antibodies to the analyte. Since pesticides are small molecules. pesticide derivatives. namely haptens. must be synthesized and coupled 10 carricr proteins to induce antibody production. One lype of hapten for organoplosplionus pesticides is one with an amino carboxylic acid bridge at 1hiophosplate group. which has been used successfully in the development of ELISA for several organophosplionis pesticides. ${ }^{-12}$ We have dereloped a novel method for the synthesis of such haptens. which is much casier than the previous one. "I This paper describes the application of this melhod to the synthesis of taptens for bromophos from which specific polyclonal antibodies to bromophos were oblained. Using the antibodics. a sensitive and selective ELISA for bromophos was developed.

\section{Experimental Section}

Reagents and Instruments. Organophosphorus pesticides including bromoplos were purcliased from Dr. Ehrenstorfer (Augsburg. Germany). BSA. OVA. peroxidase labeled goat anti-rabbit IgG. Freund's complete and incomplete adjurants. and Scphadex G-25 were purclased from Sigma (St. Louis. USA). Tetramelhylben/idine was oblained from Bochringer Manulıcim (Mannheim. Germany). Other chemicals were from Aldrich (Milwaukce. USA). Analytical (silica gel F25t) and preparative TLC plates (silica gel. $1 \mathrm{~mm}$ ) were purchased from Merck (Darmstadt. Germany). The dialysis membranc (MW cutoff 12000-14000) was obtaincd from Spectrum Laboratorics (Rancho Dominguc\%. USA). Microtiler plates (Maxisorp. 439454) were purclased from Nunc (Roskilde. Denmark). ELISA plates were washed with a Model 1575 ImmunoWash from Bio-Rad (Hercules. USA) and well absorbances were read with a Vmax microplate reader from Molecular Der ices (Menlo park. USA). NMR specira were obtained with a Bruker (Rhcinstetten. Germany) ARX spectrometer $(300 \mathrm{MH} z)$. Chemical shift values are given relative to internal tetramethylsilane. Coupling constants are expressed in $\mathrm{H} \%$ and the abbreviations s. d. t. qn. m. and ar represent singlet. doublet. triplet. quintel. multiplet. and aromatic. respectively.

Hapten Synthesis. The haptens used for immunization and ensyme tracer are presented in Figure 1. The synthelic routes for the haptens are illustrated in Figure 2. The procedure for the synthesis of Hapten A was as follows.

$O$-Methyl $O$-(4-Bromo-2,5-dichlorophenyl) Phosphorochloridothioate (3). The starting matcrial 4-bromo-2,5dichlorophenol (2) was synthesized by a published proce- 
<smiles>COP(=S)(OC)Oc1cc(Cl)c(Br)cc1Cl</smiles>

Bromophos

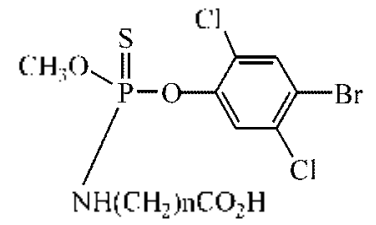

Hapten $A: n=3$

Hapten $B: n=5$

Figure 1. Structures of the haptens for hromophos used for inmmunization and enzyme-tracer. $\underline{1}$

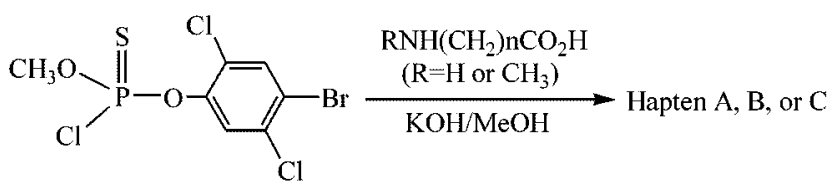<smiles>COP(=S)(Cl)Cl</smiles>

Figure 2. Synthetic rout ior haptens.

dure. ${ }^{1 . \grave{ }}$ A solution of $\underline{\mathbf{2}}(+\mathrm{g} .17 \mathrm{mmol})$ in $5 \mathrm{~mL}$ of acetonitrile was added dropwise to a stirred mixture of $1.6 \mathrm{~g}$ (9.6 mmol) of $\underline{1}^{1+} 15 \mathrm{~g}$ of finely ground $\mathrm{K}_{2} \mathrm{CO}_{3}$ and $20 \mathrm{~mL}$ of acetonitrile. After stirring for $\mathrm{l} h$ at room temperature. the misture was filtered through celite, and the solvent was removed under reduced pressure. The residue was subjected to column chromatography (silica gel. 6:1 hexane/benzene. $\left.R_{f}: 0.60\right)$ to give $1.6 \mathrm{~g}(44 \%)$ of the product $(\underline{3})$ as a colorless oil. 'H NMR ( $\mathrm{CDCl}_{3}$ ): $\$ 7.73$ (lH. s, ar). 7.59 (lH. s, ar). $4.06\left(3 \mathrm{H}, \mathrm{d} . j=1+.3, \mathrm{CH}_{3} \mathrm{OP}\right)$.

Hapten A. To a stirred solution of $570 \mathrm{mg}(1.5 \mathrm{mmol})$ of $\underline{\mathbf{3}}$ in $0.5 \mathrm{~mL}$ of methanol cooled in an ice-water bath was added dropwise a solution of $322 \mathrm{mg}(4.0 \mathrm{mmol})$ of $\mathrm{KOH}$ and 170 $\mathrm{mg}$ (1.65 mmol) of 4-aminobutyric acid in $1.7 \mathrm{~mL}$ of methanol. After stirring for $5 \mathrm{~min}$. the reaction mixture was filtered and extracted with $1 \mathrm{~N} \mathrm{HCl}$-chloroform. The extract was dried over $\mathrm{MgSO}_{4}$ and the solvent was exaporated. Column chromatography (silica gel. 19:9:1 chloroform/ ethyl acetate/acetic acid. $\left.\mathrm{R}_{f}: 0.41\right)$ of the residue gave 258 Ing $(37 \%)$ of a white solid. ${ }^{1} \mathrm{H}$ NMR $\left(\mathrm{CDCl}_{3}\right): \delta 7.66(1 \mathrm{H}, \mathrm{d}$. $J=1.0$. ar). 7.63 (lH. d. $J=1.6$ ar). $3.82(3 \mathrm{H}, \mathrm{d} . J=1+.1$. $\left.\mathrm{CH}_{3} \mathrm{OP}\right), 3.49(1 \mathrm{H}, \mathrm{m}, \mathrm{NH}), 3.19(2 \mathrm{H}, \mathrm{t} \times \mathrm{d} . J=12.5 \& 6.7$. $\left.\mathrm{NHC}_{2}\right) .2 .45\left(2 \mathrm{H}\right.$, t. $\left.J=7.1 . \mathrm{CH}_{\beth} \mathrm{CO}_{2}\right) .1 .88(2 \mathrm{H}, \mathrm{qn} . J=$
7.0. $\left.\mathrm{CH}_{2} \underline{\mathrm{C}}_{2} \mathrm{CH}_{2}\right)$.

Hapten $\mathrm{B}$ and $\mathrm{C}$ were synthesized by the same procedure as that for Hapten A. using 6-aminocaproic acid and $4-(\mathrm{A}-$ methy lamino)buty ric acid. respectively.

Hapten B. The yield was $65 \%$. TLC $\mathrm{R}_{f}: 0.42$ (silica gel. 19:9:1 chloroform/ethyl acetate/acetic acid). ${ }^{\mathrm{H}} \mathrm{H}$ NMR $\left(\mathrm{CDCl}_{3}\right): \delta 7.66$ (1H. d. $j=1.0$, ar), 7.64 (1H. d. $j=1.6$, ar), $3.82\left(3 \mathrm{H}, \mathrm{d}, J=14.2 . \mathrm{CH}_{3} \mathrm{OP}\right), 3.30(\mathrm{lH} . \mathrm{m} . \mathrm{NH}), 3.18(2 \mathrm{H}$. $\left.\mathrm{t} \times \mathrm{d}, J=10.5 \& 6.6, \mathrm{NHCH}_{2}\right) .2 .36\left(2 \mathrm{H} . \mathrm{t} . J=7.0, \mathrm{CH}_{2} \mathrm{CO}_{2}\right)$, $1.57\left(6 \mathrm{H}, \mathrm{m} . \mathrm{CH}_{2}\left(\mathrm{C}_{2}\right)_{3} \mathrm{CH}_{2}\right)$.

Hapten $\mathbf{C}$. The yield was 33\%. TLC $\mathrm{R}_{f}: 0.48$ (silica gel. 19:9:1 chloroform/ethyl acetate/acetic acid). 'H NMR $\left(\mathrm{CDCl}_{5}\right): \delta 7.66(\mathrm{lH} . \mathrm{d} . J=1.0$, ar), $7.53(\mathrm{lH} . \mathrm{d} . J=1.6, \mathrm{ar})$, $3.77\left(3 \mathrm{H}, \mathrm{d}, J=14.0, \mathrm{CH}_{3} \mathrm{OP}\right) .3 .35\left(2 \mathrm{H}, \mathrm{ml}, \mathrm{NC} \underline{\mathrm{H}}_{2}\right), 2.87$ $\left(3 \mathrm{H} . \mathrm{d}, J=11.3 . \mathrm{CH}_{3} \mathrm{~N}\right), 2.43\left(2 \mathrm{H} . \mathrm{t} . J=7.4 . \mathrm{C}_{2} \mathrm{CO}_{2}\right) .1 .92$ (2H. qli. $J=7.3 . \mathrm{CH}_{2} \underline{\mathrm{C}}_{2} \mathrm{CH}_{2}$ ).

Preparation of Hapten-protein Conjugates. Hapten A and $B$ were covalently attached to BSA to be used as immumogens. Hapten $B$ was also attached to OVA to be used as the coating antigen for serum screening. Hapten A. B, and $C$ were conjugated to HRP to be used as enzyme tracers. The method of conjugation used was the active ester method. ${ }^{7,5}$ The structure of the active ester in the case of Hapten $A$ is shown in Figure 3. The procedure for the synthesis of this ester is described below: Other active esters were synthesized by the same procedure. To a solution of A-hydroxysuccinimide (28 $\mathrm{mg} .0 .24 \mathrm{mmol}$ ) dissolved in dichloromethane $(5 \mathrm{~mL})$ were added Hapten A (97 $\mathrm{mg} .0 .22 \mathrm{mmol})$, t-dimethylaminopy ridine $(2.7 \mathrm{mg} .0 .022 \mathrm{mmol})$, and $\mathrm{AA}$ dicyclohexy lcarbodiimide $(63 \mathrm{mg} .0 .24 \mathrm{mmol}$ ). The mixture was stirred for $2 \mathrm{~h}$ and then filtered to remove the dicyclohexylurea. and the solvent was evaporated. Chromatography of the resultant oil on silica gel using chlorform/ethyl acetate/acetic acid (19:9: $1 \mathrm{R}_{f}: 0.52$ ) followed by preparative TLC using the same eluent gave the active ester as a syrup (5l mg. 40\%). 'H NMR ( $\left.\mathrm{CDCl}_{3}\right): \delta 7.67$ (1H. s. ar). 7.62 (lH. d. $J=1.6$. ar). $3.82\left(3 \mathrm{H} . \mathrm{d} . J=14.8, \mathrm{CH}_{3} \mathrm{OP}\right) .3 .57$

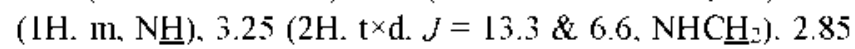
(H. s. succimyl). $2.73\left(2 \mathrm{H} . \mathrm{t} . J=6.9, \mathrm{CH}_{2} \mathrm{CO}_{2}\right), 1.98(2 \mathrm{H} . \mathrm{m}$. $\left.\mathrm{CH}_{2} \mathrm{C}_{2}-\mathrm{CH}_{2}\right)$.

Active Ester of Hapten B. Yield 34\%. TLC $R_{f}: 0.52$ (silica gel. 19:9: 1 chloroform/ethyl acetate/acetic acid). ${ }^{\prime} \mathrm{H}$ NMR (CDCl $\left.)_{i}\right): \delta 7.67$ (lH, d. $J=0.8$ ar). $7.6+(1 \mathrm{H}, \mathrm{d}, J=$ 1.5. ar). 3.89 (3H. d. $\left.J=14.3 . \mathrm{CH}_{.3} \mathrm{OP}\right), 3.40(1 \mathrm{H}, \mathrm{m} . \mathrm{NH})$. $3.16\left(2 \mathrm{H} . \mathrm{t} \times \mathrm{d} . J=11.4 \& 6.6 . \mathrm{NHCH}_{2}\right) .2 .85(4 \mathrm{H}, \mathrm{s}$. succinyl). $2.64\left(2 \mathrm{H}\right.$. t. $\left.J=7.1, \mathrm{CH}_{2} \mathrm{CO}_{2}\right), 1.58(6 \mathrm{H}, \mathrm{m}$. $\left.\mathrm{CH}_{2}\left(\underline{\mathrm{C}}_{2}\right)_{3} \mathrm{CH}_{2}\right)$.

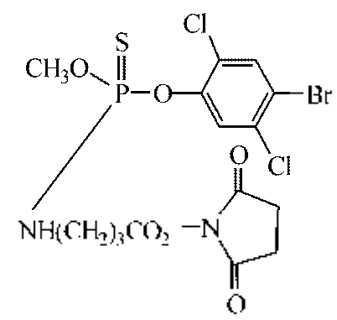

Figure 3. Structurc of active ester of Hapten A. 
Active Ester of Hapten C. Yield 33\%. TLC R $\mathrm{R}_{f}: 0.62$ (silica gel. 19: 9 : 1 cllorofonn/etlyyl acetate/acetic acid). ${ }^{1} \mathrm{H}$ NMR $\left(\mathrm{CDCl}_{3}\right): \delta 7.66(1 \mathrm{H}, \mathrm{d}, J=0.9$, ar $) .7 .53(1 \mathrm{H}, \mathrm{d}, j=$ 1.6. ar) 3.78 ( $\left.3 \mathrm{H} . \mathrm{d}, J=1+.1 . \mathrm{CH}_{3} \mathrm{OP}\right) .3 .39$ ( $\left.2 \mathrm{H}, \mathrm{m} . \mathrm{NC} \mathrm{H}_{2}\right)$, 2.89 (3H. d. $J=11.2$. $\mathrm{CH}_{3} \mathrm{~N}$ ). 2.85 ( + H. s. succinyl). 2.69 (2H. t. $\left.J=7.5 . \mathrm{C}_{2} \mathrm{CO}_{2}\right), 1.93\left(2 \mathrm{H}, \mathrm{m} . \mathrm{CH}_{2} \mathrm{C}_{2} \mathrm{CH}_{2}\right)$.

The procedures for coupling haptens to the camier proteins were as follows. To prepare hapten-BSA conjugates (immunogens). BSA (20 $\mathrm{mg}$ ) was dissolved in $2 \mathrm{~mL}$ of borate buffer (0.2 M. pH 8.7) to which $0.4 \mathrm{~mL}$ of DMF was added. A solution of an active ester ( $16 \mathrm{mg} .0 .03 \mathrm{mmol}$ ) dissolved in $0.1 \mathrm{~mL}$ of $\mathrm{DMF}$ was then added to the stirred protein solution. and stirring was continued overnight at $+{ }^{\circ} \mathrm{C}$. Hapten-OVA conjugate (coating antigen) was prepared by the same procedure. Hapten-HRP conjugates (enzz me tracers) were prepared by the same procedure except that four hapten/protein molar ratios $(5,10.20$ and 50$)$ were employed. The conjugates for immunogen and coating antigen were separated from the uncoupled haptens by gel filtration (Sepladex G-25) using PBS (10 $\mathrm{mM}$ phosphate buffer. 137 $\mathrm{mM} \mathrm{NaCl}, 2.7 \mathrm{mM} \mathrm{KCl}$. pH 7.4). Finally. the eluates were dialyzed in water overnight and then freeze-dried. The conjugates for enzyme tracer were separated from the uncoupled haptens by dialysis in PBS for two days and in water for one day and then stored at $4^{\circ} \mathrm{C}$.

Immunization of Rabbits. Female New Zealand white rabbits were immunized with Hapten A- or Hapten B-BSA. Routinely: $500 \mu \mathrm{g}$ of the conjugate dissolved in $500 \mu \mathrm{L}$ of PBS was emulsified with Freund's complete adjurant $(1: 1$ volume ratio) and injected intradennally at multiple sites on the back of each rabbit. After two weeks. each animal was boosted with an additional $500 \mu \mathrm{g}$ of the conjugate emulsified with Freund's incomplete adjuxant and bled from seren to ten days later. After this. boosting and bleeding was continued on a montlly basis. Serum was isolated by centrifugation. and sodium azide was added as a preservative at a final concentration of $0.02 \%$. Serum was then aliquoted and stored at $-70^{\circ} \mathrm{C}$.

Screening of Antisera. Several dilutions of each senum were titrated against the coating antigen (Hapten B-OVA. $1000 \mathrm{ng} / \mathrm{well}$ ) to measure the reactivity of antibodies. Flatbottom polysty rene microtiter plates were coated with the coating antigen ( $10 \mu \mathrm{g} / \mathrm{mL}, 100 \mu \mathrm{L} / \mathrm{we}$ ell $)$ in $50 \mathrm{mM}$ carbonate-bicarbonate buffer $(\mathrm{pH} 9.6)$ by overnight incubation at + " $\mathrm{C}$. The following day. the coated plates were washed five times with PBSTA (PBS containing 0.05\% Tween 20 and $0.02 \% \mathrm{NaN}_{3}, \mathrm{pH} 7 .+$ ) and were blocked by incubation with $1 \%$ gelatin in PBS $\left(200 \mu \mathrm{L} /\right.$ well) for $\mathrm{I}$ h at $37^{\circ} \mathrm{C}$. After another washing step $100 \mu \mathrm{L} /$ well of antisenum diluted with PBSTA (1/10000-1/1250000) was added to the plate and incubated for $\mathrm{l}$ h at $37^{\circ} \mathrm{C}$. After another washing step 100 $\mu \mathrm{L} /$ well of goat anti-rabbit IgG conjugated with alkaline phosphatase diluted $1: 2000$ with PBSTA was added to the plate and incubated for $1 \mathrm{~h}$ at $37^{\circ} \mathrm{C}$. Then the plates were washed again and $100 \mu \mathrm{L} /$ well of $p$-nitrophenyl phosphate $(1 \mathrm{mg} / \mathrm{mL}$ ) dissolved in $10 \%$ diethanolamine buffer $(\mathrm{pH} 9.8)$ was added to the plate. After incubation at $37^{\circ} \mathrm{C}$ for $30 \mathrm{~min}$. the reaction was stopped by adding $50 \mu \mathrm{L}$ of $3 \mathrm{~N} \mathrm{NaOH}$ and absorbance was read at $405 \mathrm{~nm}$.

Competitive Direct Assay. Checkerboard assayss, in which various dilutions of the sera were titrated against varying amounts of enzy me tracers (Hapten A. B or C conjugated to HRP). were used to select the most suitable antiserum and enzyme tracer. and to have a rough estimate of their appropriate concentrations for competitive assays. The procedure for the checkerboard assays was the same as that for competitive assays (see below) except that only solvent instead of pesticide solution was added at the competition step. After selecting the most suitable antiserum and enzyme tracer from the checkerboard assays, their quantities for the competitive direct assays were optimized. Additionally: the tolerance of ELISA to various water-miscible organic solvents used to dissolve pesticides was tested for assay optimization. For this test. standard pesticide solutions were prepared in acetone. acetonitrile. or methanol of various concentration levels $(2.5 .5,10.20$ and $40 \%$ in PBS resulting in a final concentration of $1.25,2.5,5,10$, and $20 \%$, respectively: by combining with the enzyme tracer diluted with $10 \mathrm{mM}$ PBS). The influence of buffer concentration of assay solution on ELISA performance was also studied using different concentrations of phosphate in $5 \%$ methanolPBS to dissolve the pesticide (10.90, 190 and $390 \mathrm{mM}$ phosphate resulting in the final concentration of $10,50,100$ and $200 \mathrm{mM}$, respectively, by combining with the enzyme tracer diluted with $10 \mathrm{mM}$ PBS). The influence of $\mathrm{pH}$ of the assay solution on assay parameters was also studied. The media of the assay solutions were $5 \%$ methanol-PBS buffer $(50 \mathrm{mM})$ at various $\mathrm{pH}$ values.

The direct assays were performed as follows. All incubations except that for precoating the wells with protein $\mathrm{A}$ were carried out at $25^{\circ} \mathrm{C}$. Microtiter plates were coated with protein $\mathrm{A}(5 \mu \mathrm{g} / \mathrm{mL}, 100 \mu \mathrm{L} / \mathrm{well})$ in carbonate-bicarbonate buffer $\left(50 \mathrm{mM}\right.$. pH 9.6) by orernight incubation at $4^{\circ} \mathrm{C}$. The plates were washed five times with PBST and coated with $100 \mu \mathrm{L} /$ well of the antiserum dilutions in PBS for $1 \mathrm{~h}$. After another washing step. serial dilutions of the analyte in MeOH-PBS were added (50 $\mu \mathrm{L} / \mathrm{well}$ ) followed by $50 \mu \mathrm{L} /$ well of an enzyme tracer previously diluted with PBS (500) $\mathrm{ng} / \mathrm{mL}$ ). After incubation for $\mathrm{I} h$ and another washing step. $100 \mu \mathrm{L} /$ well of a TMB solution $(400 \mu \mathrm{L}$ of $0.6 \%$ TMBDMSO and $100 \mu \mathrm{L}$ of $1 \% \mathrm{H}_{2} \mathrm{O}_{2}$ diluted with $25 \mathrm{~mL}$ of citrate-acetate buffer. $\mathrm{pH} 5.5$ ) were added. The reaction was stopped after an appropriate time by adding $50 \mu \mathrm{L}$ of $2 \mathrm{M}$ $\mathrm{H}_{2} \mathrm{SO}_{7}$ and absorbance was read at $450 \mathrm{~mm}$. Competition curves were obtained by plotting absorbance against the logarithm of analyte concentration. Sigmoidal curves were fitted to a four-parameter logistic equation. ${ }^{1 / 6}$ from which $\mathrm{IC}_{\overline{x i c}}$ values (concentration at which binding of the antibody to the coating antigen is inhibited by $\mathbf{5 0 \%}$ ) were determined.

Determination of Cross-reactivities. Several organophosphonis pesticides and the metabolite of bromophos (phenol) were tested for cross-reactivity using the direct ELISA procedure described above. The cross-reactivity values were calculated as follows: ( $\left(\mathrm{IC}_{i,}\right.$ of bromophos $/ \mathrm{IC}_{i, i}$ of compound) $\times 100$. 


\section{Results and Discussion}

Hapten Selection and Synthesis. A suitable hapten for immunization should preserve the structure of the target compound as much as possible. The phosphorothioate organophosphonus pesticides such as bromophos have a thiophosplate group in common and differ only in the structure of the aromatic rings. Therefore. to achieve a high selectivity in bromophos ELISA, it was desirable to synthesize immunizing haptens having a bridge at the thiophosphate group preserving the aromatic ring unique to bromophos. Haptens in this study have such structural features. Heldman et al. were the first to synthesize a hapten for OP pesticide with a spacer arm at the thiophosphate group. ${ }^{17}$ However. a generic method was developed later by Skerritt et al ${ }^{18,19}$ The method was applied to the synthesis of haptens for the development of ELISAs of several organophosphorus pesticides. ${ }^{-11}$ This method requires a synthetic route involving seven steps including protection and deprotection of both amino and carboxyl groups. In an effort to simplify the synthetic process for this class of haptens we developed a simpler generic method which requires only two steps. It involves the reaction of $O$-methyl (etlyl) dichlorothiophosphate with a phenol and $\mathrm{K}_{2} \mathrm{CO}_{3}$ in acetonitrile and the reaction of the substitution product with an amino carboxylic acid (not protected) and $\mathrm{KOH}$ in methanol. This method was successfully applied to the synthesis of three haptens for bromophos (Figure 1). The reactions proceeded facily with relatively ligh yield: $44 \%$ and $33-65 \%$ in the first and second reaction. respectively. The reaction time was relatively short: $l \mathrm{~h}$ and a few minutes for the first and second reaction. respectively. This method was successfully applied in this laboratory for the synthesis of haptens of several other OP pesticides such as clilorpyrifos. ${ }^{12}$ diazinon. fenitrothion. parathion-methy l. cyanophos $\mathrm{s}^{-1)}$ and isofenphos. ${ }^{21}$ and we applied for a patent. All the carboxylic acid haptens could be comverted to the succinimide esters, active esters for coupling haptens to carrier proteins.

Direct Competitive Assay. The checkerboard assays, in which several dilutions of the sera were titrated against varying amounts of the enzyme tracers, were used to select the most suitable antiserum and enzyme tracer and to optimize enzyme tracer and antibody concentrations. The optimum combination selected was the combination of the senum from Hapten A-BSA (3rd boost) diluted $1 / 2000$ and the tracer Hapten B-HRP prepared at $10: 1$ hapten/protein molar ratio and diluted to $500 \mathrm{ng} / \mathrm{mL}(25 \mathrm{ng} / \mathrm{well})$.

Since the use of organic solvents for extraction and/or solid phase clean up is very common in the analysis of nonpolar pesticide residues in food and erwironmental samples. it is desirable to assess the effect of organic solvents on ELISA performance. The effects of solvents (acetone. acetonitrile. and methanol) on the ELISA system were evaluated by preparing standard curves in buffers containing various amounts of solvent $(1.25 .2 .5 .5,10$. and $20 \%$ in PBS). The results are presented in Table 1. These solvents significantly influenced assay performance. The speed of color develop-
Table 1. Intluence of organic cosolvent concentration of assay solution on assily perameters of direct LLISA ${ }^{a}$

\begin{tabular}{|c|c|c|c|c|}
\hline & $\begin{array}{c}\text { Concentration } \\
\left({ }_{0}{ }_{0}\right)\end{array}$ & $\mathrm{Abs}_{\text {nila: }}$ & Slope & $\begin{array}{c}\mathrm{IC}_{50} \\
(\mathrm{ng} \mathrm{ml})\end{array}$ \\
\hline \multirow[t]{5}{*}{ Avelone } & 1.25 & 0.892 & 1.775 & 75 \\
\hline & 2.5 & 1.221 & 0.872 & 46 \\
\hline & 5 & 0.478 & 1.137 & 191 \\
\hline & 10 & 0.308 & 0.733 & 75 \\
\hline & $200^{k}$ & & & \\
\hline \multirow[t]{4}{*}{ Acetonitrile } & 2.5 & 1.860 & 0.958 & 137 \\
\hline & 5 & 1.478 & 0.868 & 331 \\
\hline & 10 & 0.922 & 1.078 & 196 \\
\hline & 20 & 0.302 & 0.998 & 192 \\
\hline \multirow[t]{5}{*}{ Methanol } & 1.25 & 0.894 & 0.711 & 92 \\
\hline & 2.5 & 1.016 & 0.711 & 43 \\
\hline & 5 & 0.667 & 0.983 & 207 \\
\hline & 10 & 0.233 & 0.651 & 127 \\
\hline & $20^{\circ}$ & & & \\
\hline
\end{tabular}

" $\Lambda$ ssay conditions: precoating with protein $\Lambda(0.5 \mu \mathrm{g}$ well): antiscrum to Ilapten $A-B S \wedge$, diluted I 2000 with 10 mM PBS: enzy me tracer: I lapten B-HRl? $500 \mathrm{ng} \mathrm{mL}$. Data are the means of duplicales. Parameters were obtained from the four-parameter sigmoidal litting. "Data litting was inposible duc to poor color developtnetrt.

ment (estimated from $\mathrm{Abs}_{\text {tus. }}$ ) at the competition step decreased rapidly with increasing concentration of organic solvent resulting in more than $50 \%$ retardation of color development above $10 \%$ concentration. Based on the relatively high $A \mathrm{Abs}_{\text {tuax }}$ value and the lowest $I \mathrm{C}_{5,1}$ value. methanol at $2.5 \%$ concentration was selected as the optimum composition for the assay. Several other workers reached the same conclusion as ours in that methanol caused the least negative effect on the performance of the assay. $2 ., ? 3$

Varying the concentration of the phosphate buffer in the competition solution had no significant effect on the assay sensitivity (data not shown). The optimum concentration selected was $50 \mathrm{mM}$ phosphate which showed the lowest $\mathrm{IC}_{50}$ value. Table 2 presents the effect of $\mathrm{pH}$ of assay solution on ELISA. IC $\mathrm{C}_{5, \mathrm{~V}}$ values were similar at the $\mathrm{pH}$ 's from 6.0 to 7.4. Based on the relatively high $A_{\max }$ value and slope of the calibration curve. $\mathrm{pH} 7.0$ was selected as the best one.

Figure + shows a typical inhibition cure obtained under the optimized condition. The $I C_{5 i}$, value of the assay was to

Table 2. Influence of pII of assay solution on assaly parameters of diroct LLISA ${ }^{a}$

\begin{tabular}{cccc}
\hline $\mathrm{pH}$ & Abs $_{\operatorname{mix}}$ & Slope & $\begin{array}{c}\mathrm{IC}_{50} \\
(\mathrm{ng} / \mathrm{mI})\end{array}$ \\
\hline 6.0 & 0.873 & 0.690 & 31 \\
6.5 & 1.059 & 0.845 & 41 \\
7.0 & 1.092 & 0.839 & 36 \\
7.4 & 1.191 & 0.713 & 49 \\
8.0 & 0.629 & 1.737 & 256 \\
9.0 & 0.626 & 0.751 & 67 \\
100 & 0.344 & 0.801 & 79 \\
\hline
\end{tabular}

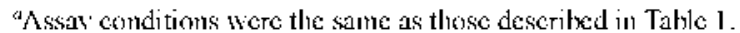




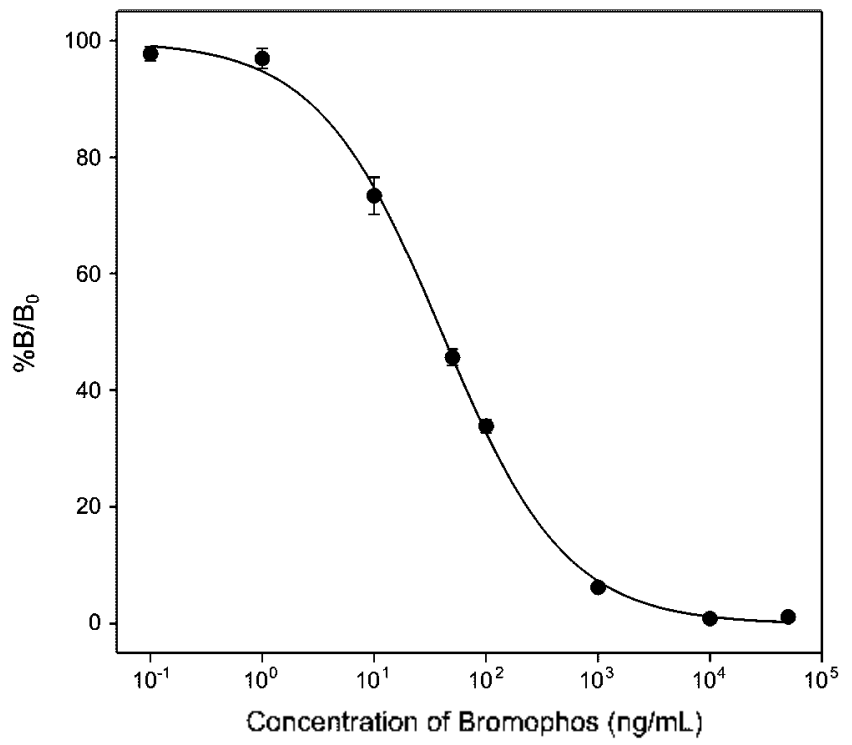

Figure 4. FI.ISA inlibition curves for bromophos by direct competitive assay. Assay conditions were the wame as those described in liable $1 . \% \mathrm{~B} / \mathrm{B}_{0}=\left(\mathrm{A}-\mathrm{A}_{x \times} / \mathrm{A}_{0}-\mathrm{A}_{\mathrm{x}}\right) \times 100$, where $\mathrm{A}$ is the absorbance at a oiven concentration of the analyte, $A_{0}$ is the absorbance at 7ero dose of the analyte, and $\Lambda_{x}$ is the absorbance at an excess of the analyte. Lach point represents the mean of 24 deteminations. Vertical bars indicale \pm SL) about the mean.

Table 3. Cross-reactivity of compounds structurally related to bromophos detennined by diree competitive LiLIS ${ }^{a}$

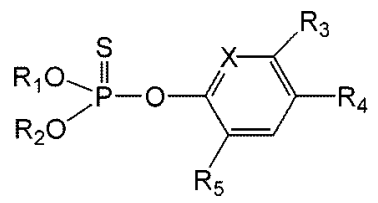

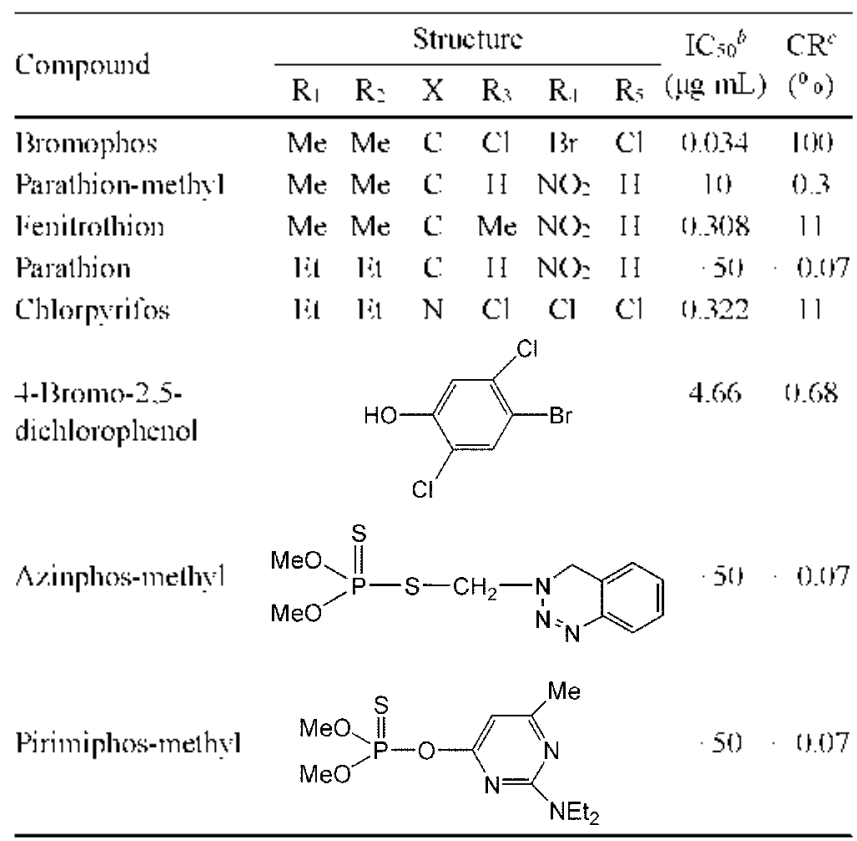

"Assay conditions were the same as those described in Table 1. "IC $\mathrm{C}_{-.1}$ values of parathion, azinphos-methyl and pirmiphos-metlyyl could not be determined aceutately due to the limited solubility at high concentrations. honsever. it was clear that inhibition was less than $50^{\circ} \mathrm{o}$ at 50 !g

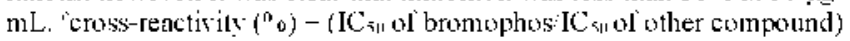
100 . $\mathrm{ng} / \mathrm{mL}$ with a detection limit of $7 \mathrm{ng} / \mathrm{mL}$ ( $20 \%$ inlubition).

Cross-Reactivity Studies. Several organophosphorus pesticides as well as the metabolite of bromophos (phenol) were tested for cross-reactivities. Table 3 shows the crossreactivity that was found by the direct assay described above. expressed in percentage of the IC $\mathrm{C}_{5, \mathrm{l}}$ of bromophos. The interference to the assays was negligible except with chlorpyrifos and fenitrothion. The appreciable cross-reactivities of antibodies for these pesticides are understandable. because they have similar aromatic structure as bromophos. It may be concluded that the competitive ELISA that was developed is suitable for the sensitive and selective detection of bromophos. with the exception of chlorpy rifos and fenitrothion.

Acknowledgment. This work was supported by Korea Research Foundation Grant (KRF-2000-GA0023). Additional support from NIEHS Superfund Basic Research Program P42 ES04699 and NIEHS Emvironmental Health Center P30 ES05707 of USA are also acknowledged.

\section{References}

1. AOAC Intemational. Official Methods of Anahsis. 18th ed.: AOAC Intemational: Arlington, VA, 1995; Section 970.52

2. Jung. F.: Gee. S. J.: Harison. R. O.: Goodrow. M. H.: Kanu. A. E.: Bratn. A. L.: Li. Q. X.: Hammock. B. D. Pestic. Sci. 1989. 26. 303-317.

3. Marco, M. P.: Gec, S. I.: I Iammock. B. D. Thends fnd. Chem. 1995, 14. 415-425

4. IIennion, M. C.: Bareclo, D. Anat. Chim. Acta 1998, 362. 3-34

5. Hassull. K. A. The Biochemistry and Itses of Pesticides. $\mathrm{VCH}$ New York. 1990: p 122.

6. Eichler. D. Residhe Ret 1972. H/.65-112.

7. Me^dam, D. P.: Hill, A. S.: Beaslev. II. I..: Skerritt, I. H. J. Agric. Food $/ \mathrm{C} / \mathrm{km} .1992,+0.1466-1470$.

8. Skerritt. I. II.: I Hill, A. S.: Thwaites, II. I..: F.dward. S. I..: McAdam. D. P.J. HO.K Iht. 1992. 73. 519-528.

9. Edward. S. L.: Skerritt. J. H.: Hill. A. S.: McAdam. D. P. Food igric. Immmol 1993. 5. 129-144.

10. I Iill, A. S.: Skerritt, I. II.: Bushway, R. I.: Perhins. I.. B.: I.arkin, K.: Thomas. M: Korth, W.: Bowmer. K. H. J. fgric Food Chem. $1994,+2.2051-2058$

11. Manclus. J. J.: Primo. J.: Montova. A. J. Igrtc. Food Chem 1996. H. $4052-4062$

12. Cho. Y. A.: Lee. H.-S.: Park. E. Y.: Lee. Y. T.: Hammock. B. D.: Alun, K. C.: I.ce. J. K. Bull. Kornem Chem Soc. 2002. 23, $481-487$.

13. Ross, F.: Park. V. III \&S paten 1973, 3.728. 40.3

14. Tabor. F. J. LS Fot'm 1961. 3.005.005

15. Hassner. A.: Alexanian. V. Tetrahedhon Ieft 1978, 46. 4475-4478.

16. Raab. G. M. Clin. Chem. 1983. 29.1757-1761.

17. Heldman. E.: Balan. A.: Horowitz. O.: Ben-Zion. S.: Torten. M. FEBS Lett 1985, 180. 24.3-248.

18. Mc^dam, D. P.: Skerritt. I. II. Anst. J. Chem. 1993, 46. 959-967.

19. Skerritt, J. H.; I ce, N. J. In Residue Analusis in Food Safen: ipplications of Immunoassay lothods. Beier R. C. Stanker. L. H.. Eds.: ACS Symposium Series 621: American Chemical Sociey: Washington DC. U. S. A. 1996: pp 124-149.

20. Park, I. I I.: Kim, Y. I.: I ce, Y. T. Bull Sorean Chem Soc. 2002. 23. $605-609$.

21. Park, H. I.: Park, W. C.: Jung, T.; Rha, C. S.: I.ce, Y. T. Bull Konean (hem. Soc. 2002. 23. $599-604$.

22. Hill. A. S.: McAdam. D. l:: Edward. S. L.: Skerrill. J. H. J. lgric.

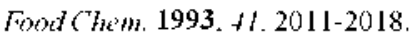

23. I.ee, I. G.: A Hur. K. C.: Park, O. S.: Kang. S. Y.: Hammock; B. D. J. Agric. Food hem 2001, +9. $2159-2167$ 